\title{
Honey moisture reduction using several thermal methods and their effects on its quality
}

\author{
Firman Jaya ${ }^{1,2}$, Lilik Eka Radiati $^{2 *}$, Teti Estiasih $^{3}$, Djalal Rosyidi ${ }^{2}$, Anang Lastriyanto ${ }^{4}$ \\ Mochammad Junus ${ }^{5}$, Jati Batoro ${ }^{6}$, Erwan Erwan ${ }^{7}$, Jacobus Suruka Aifaman Lamerkabel ${ }^{8}$, \\ Dewi Masyithoh ${ }^{9}$, Ustadi Ustadi ${ }^{10}$, Eggi Pur Pinandita ${ }^{11}$
}

\begin{abstract}
${ }^{1}$ Animal Science Doctoral Program, Faculty of Animal Science, Universitas Brawijaya, Malang 65145, East Java, Indonesia

${ }^{2}$ Department of Animal Products Technology, Faculty of Animal Science, Universitas Brawijaya, Malang 65145, East Java, Indonesia

${ }^{3}$ Department of Agricultural Product Technology, Faculty of Agricultural Technology, Universitas Brawijaya, Malang 65145, East Java, Indonesia

${ }^{4}$ Department of Agricultural Engineering, Faculty of Agricultural Technology, Universitas Brawijaya, Malang 65145, East Java, Indonesia

${ }^{5}$ Department of Animal Products, Faculty of Animal Science, Universitas Brawijaya, Malang 65145, East Java, Indonesia

${ }^{6}$ Department of Biology, Faculty of Mathematics and Natural Sciences, Universitas Brawijaya, Malang 65145, East Java, Indonesia.

${ }^{7}$ Department of Animal Husbandry, Faculty of Animal Science, University of Mataram, Mataram 83125, Indonesia

${ }^{8}$ Department of Agrotechnology, Faculty of Agriculture, University of Pattimura, Ambon 97233, Indonesia

${ }^{9}$ Department of Animal Husbandry, Faculty of Animal Husbandry, Islamic University of Malang, Malang 65144, Indonesia

${ }^{10} \mathrm{PT}$. Kembang Joyo Sriwijaya, Malang 65152, Indonesia

${ }^{11}$ Animal Science Magister Program, Faculty of Animal Science, Universitas Brawijaya, Malang 65145, East Java, Indonesia
\end{abstract}

\begin{abstract}
Honey is thermally heated at various methods to decrease the moisture content and prolong the shelf life. The heating methods might decrease the quality of honey's physicochemical and biochemical properties. The present study thermally treated the honey with a pasteurizer, evaporator, and dehumidifier. The most thermally affected to decrease the moisture content were treatment by dehumidifier $(14.09 \%)$, subsequent evaporation $(8.41 \%)$, and pasteurization $(8.41 \%)$. After heating, significant differentiation was also observed in the variation of both HMF (Hydroxymethylfurfural) content and diastase activity according to the botanical origin of the honey sample. In line with the biochemical analysis of honey, total phenolic decreased significantly during the pasteurization treatment. Evaporation was the most resistant thermal treatment due to its ability to maintain the level of HMF and the enzyme diastase as a standard for honey quality. However, changes made
\end{abstract}

\footnotetext{
* Corresponding author: lilik.eka@ub.ac.id
} 
in physicochemical and biochemical quality are still in compliance with national and international legal limits.

\section{Introduction}

Honey is sweet due to monosaccharides and viscous liquid, about $17-22 \%$ of moisture [1]. The amount of water found in honey determines its balance against fermentation and crystallization. Therefore, it is vital to procedure the honey by subjecting it to thermal remedy to prevent fermentation through yeasts [2]. Heating eases the bottling manner by reducing honey's viscosity, reducing honey's water content material to prevent fermentation, and delaying crystallization in honey [3].

Previous studies have shown that based on moisture reduction systems [4] such as, developed a small-scale honey dehydrator to reduce the moisture content of honey beneath 17\%. Furthermore, Singh et al. [5] set a desiccant honey dehydrator that heats and dehumidifies air to reduce honey's moisture content using a silica gel desiccant bed. While studies on microwave-based honey moisture reduction, such as Cui et al. and Kowalski et al. $[6,7]$, have been investigated microwave vacuum as a capability approach for obtaining high-quality dried honey. Few studies are using the drying method and comparing it with other honey moisture reduction.

The present study aims to compare methods between heating and drying processes such as pasteurization, dehumidification, and evaporation to measure the effect of thermal heating on honey quality in Indonesia. In the literature, there is limited studies effect of thermals such as pasteurization, dehumidification, and evaporation on the quality of honey. The current study aims to determine the best method for honey moisture reduction using heating and drying processes based on physicochemical and biochemical analysis.

\section{Materials and methods}

\subsection{Samples}

Fresh honey samples from different botanical origins were obtained from a representative from three areas in Indonesia: four honey samples from Jawa Barat (west), two from Ambon (east), and two from Nusa Tenggara Timur (central). In total, eight samples were studied: six samples were from monofloral honey came from Jawa Barat (rubber and rambutan), Ambon (kosambi and jambu bol), and Nusa Tenggara Timur (kosambi and eucalyptus), and one from mango honeydew (Jawa Barat), while the other one was multiflora nectar honey from different plant species (Jawa Barat). Honey samples from Jawa Barat were provided from honey bee cultivation, while honey samples from Ambon and Nusa Tenggara Timur were from wild forest honey bees (Apis dorsata). Honey samples were stored at $-18{ }^{\circ} \mathrm{C}$ until analysis.

\subsection{Honey thermal treatment}

\subsubsection{Pasteurization}

The pasteurization was evaluated according to Wibowo et al. [8]. It was a colonized form (3 double jacket pans) equipped with a control system to regulate the temperature and a 
temperature sensor (thermocouple type-K), as shown in Figure 1. Honey was heated at $65^{\circ} \mathrm{C}$.

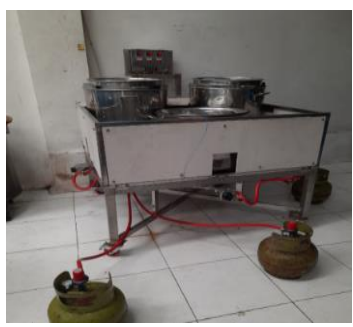

(A)

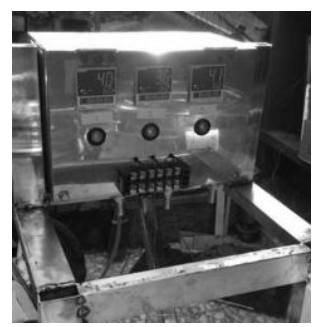

(B)

Fig. 1. Pasteurization with the colonized method (A) and control system box (b)

\subsubsection{Evaporator}

According to Lastriyanto et al. [9], the evaporator was evaluated for this research. The prototype scale evaporator became geared up with a vacuum pump jet and an evaporator tube using a heat-resistant pyrex glass flask. The heating stove layout was positioned above the water tub. The vacuum stress used became $7.8 \mathrm{kPa}$, and the temperature set on the manage box became $45{ }^{\circ} \mathrm{C}$. The stove flame will routinely decrease while the honey's temperature in the room exceeds $45^{\circ} \mathrm{C}$, consequently that the heat stays steady. The water content of honey samples was achieved each $10 \mathrm{~min}$. The evaporator is shown in Figure 2.

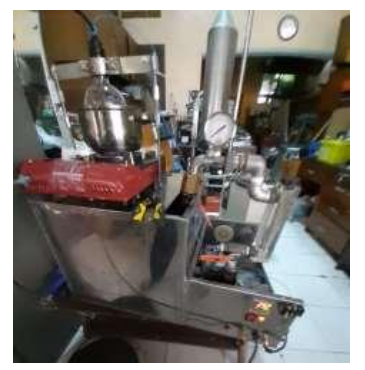

Fig. 2. Evaporator

\subsubsection{Dehumidifier}

According to Lastriyanto et al. [9], the dehumidifier used in this study was evaluated. The capacity of the water jet vacuum evaporator was $1 \mathrm{~L}$ with a portable dehumidifier with dimensions of $35 \times 32 \times 27 \mathrm{~cm}$ (Figure 3). Furthermore, the remark changed into finished through weighing every pattern's weight every 1 hour $(60 \mathrm{~min})$ until the 12 hours $(720$ min). The RH value became the lowest condition (CE) on the dehumidifier. The temperature turned into measured the usage of a type $\mathrm{k}$ thermocouple linked to Omron Ecwl 5. 


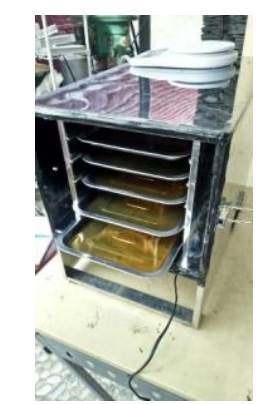

Fig. 3. Dehumidifier

\subsection{Physicochemical analysis}

Analysis for moisture content, acidity, HMF (Hydroxymethylfurfural) concentration, and diastase enzyme was estimated by the procedure of SNI 8664:2018 [10].

\subsection{Biochemical analysis}

Determination of reducing sugars and non-reducing sugar (sucrose) was carried out using SNI 8664:2018 [10]. At the same time, the total phenolic content was determined using the Folin-Ciocalteu method, and the results were expressed as $\mathrm{mg}$ gallic acid/ $\mathrm{kg}$ honey. Moreover, the total flavonoid contents of the honey samples were determined using aluminum chloride, and the results were expressed as $\mathrm{mg}$ quercetin $/ \mathrm{kg}$ honey developed by [11].

\subsection{Statistical analysis}

Statistical evaluation becomes finished on Microsoft excel for home windows. Furthermore, evaluation of variance turned into performed for the considerable distinction the usage of F-test $(P<0.05)$. All the assays had been done in triplicate, and outcomes have been expressed in mean $\pm \mathrm{SD}$.

\section{Results and discussion}

\subsection{Moisture content}

The moisture content of honey is a restricting thing for figuring out its excellent stability and spoilage resistance against yeast fermentation [12]. Eshete et al. [13] stated that honey's composition and properties rely, initially, on the floral origin concerning the geographic location and the weather regime. The initial honey samples from east Indonesia were significantly higher than the west area of Indonesia. Honey samples ranged from $19.38 \pm$ 0.80 in rubber honey in Jawa Barat to $24.57 \pm 0.54$ in kosambi tree honey in Ambon (Table 1). This investigation confirmed that the moisture content of the nonthermally-processed honey sample is a concordance to the set values of The National Standardization Agency of Indonesia [10], in which moisture content is a maximum of $22 \%$ unless shown by three samples from the east area of Indonesia. 
Heating resulted in slightly lower moisture content than raw honey, thus indicating a slight reduction in moisture content. However, no significant moisture content changed into located among honey processed at distinctive heating methods (Table 2).

This study has noticed that pasteurization did not cause a significant decrease in moisture content following the national limits. While the lowest moisture content was found using a dehumidifier. The moisture content of all types of honey was slightly decreased where pasteurization treatment of around $5.88 \%$. While evaporation treatment was decreased around $8.41 \%$, and dehumidifier is around $14.09 \%$. These results are higher than Zarei et al. [12], which was achieved in a temperature-managed water bath, and samples had been fast cooled in the ice bath at $63^{\circ} \mathrm{C}$. After $30 \mathrm{~min}$ thermal treatment, they found a lower of $0.4-0.56 \%$ in all kinds of honey.

Table 1. The quality properties of the nonthermal-processed honey sample

\begin{tabular}{|c|c|c|c|c|c|c|c|c|}
\hline $\begin{array}{c}\text { Source of } \\
\text { honey }\end{array}$ & $\begin{array}{c}\text { Moisture } \\
\text { content } \\
(\%)\end{array}$ & $\begin{array}{c}\text { Acidity } \\
\text { (mL } \\
\mathrm{NaOH} / \\
\mathbf{k g})\end{array}$ & $\begin{array}{c}\text { HMF } \\
(\mathrm{mg} / \mathrm{k} \\
\mathrm{g})\end{array}$ & $\begin{array}{c}\text { Diastase } \\
\text { activity } \\
\text { (DN) }\end{array}$ & $\begin{array}{c}\text { Reduc } \\
\text { ing } \\
\text { sugar } \\
(\%)\end{array}$ & $\begin{array}{c}\text { Non- } \\
\text { reducing } \\
\text { sugar } \\
\text { (sucrose) } \\
(\%)\end{array}$ & $\begin{array}{c}\text { Total } \\
\text { Phenolic } \\
\text { (mg/kg) }\end{array}$ & $\begin{array}{c}\text { Total } \\
\text { flavonoi } \\
\text { d } \\
(\mathbf{m g} / \mathbf{k g})\end{array}$ \\
\hline $\begin{array}{l}\text { Rubber tree } \\
\text { from Jawa } \\
\text { Barat }\end{array}$ & $\begin{array}{c}19.38 \pm \\
0.80\end{array}$ & $\begin{array}{c}18.01 \pm \\
1.43\end{array}$ & $\begin{array}{c}5.41 \pm \\
2.59\end{array}$ & $\begin{array}{c}21.17 \pm \\
0.78\end{array}$ & $\begin{array}{r}73.09 \\
\pm 0.81\end{array}$ & $\begin{array}{c}0.84 \pm \\
0.32\end{array}$ & $\begin{array}{c}372.40 \pm \\
46.31\end{array}$ & $\begin{array}{c}31.22 \pm \\
1.21\end{array}$ \\
\hline $\begin{array}{l}\text { Rambutan } \\
\text { tree from } \\
\text { Jawa Barat }\end{array}$ & $\begin{array}{c}20.72 \pm \\
1.00\end{array}$ & $\begin{array}{c}26.05 \pm \\
1.76\end{array}$ & $\begin{array}{c}5.00 \pm \\
2.86\end{array}$ & $\begin{array}{c}22.90 \pm \\
0.80\end{array}$ & $\begin{array}{r}69.54 \\
\pm 1.12\end{array}$ & $\begin{array}{c}0.43 \pm \\
0.41\end{array}$ & $\begin{array}{c}533.62 \pm \\
49.77\end{array}$ & $\begin{array}{c}35.80 \pm \\
0.98\end{array}$ \\
\hline $\begin{array}{l}\text { Honeydew } \\
\text { from Jawa } \\
\text { Barat }\end{array}$ & $\begin{array}{c}20.37 \pm \\
0.76\end{array}$ & $\begin{array}{c}42.80 \pm \\
1.98\end{array}$ & $\begin{array}{c}5.09 \pm \\
3.23\end{array}$ & $\begin{array}{c}21.10 \pm \\
0.92\end{array}$ & $\begin{array}{c}57.83 \\
\pm 0.99\end{array}$ & $\begin{array}{c}0.40 \pm \\
0.26\end{array}$ & $\begin{array}{c}723.36 \pm \\
39.32\end{array}$ & $\begin{array}{c}61.24 \pm \\
1.16\end{array}$ \\
\hline $\begin{array}{l}\text { Multiflora } \\
\text { honey from } \\
\text { Jawa Barat }\end{array}$ & $\begin{array}{c}19.92 \pm \\
0.87\end{array}$ & $\begin{array}{c}22.04 \pm \\
1.02\end{array}$ & $\begin{array}{c}5.20 \pm \\
3.76\end{array}$ & $\begin{array}{c}17.01 \pm \\
1.01\end{array}$ & $\begin{array}{c}72.79 \\
\pm 1.29\end{array}$ & $\begin{array}{c}1.65 \pm \\
1.19\end{array}$ & $\begin{array}{c}450.88 \pm \\
38.01\end{array}$ & $\begin{array}{c}28.92 \pm \\
0.76\end{array}$ \\
\hline $\begin{array}{l}\text { Eucalyptus } \\
\text { from Nusa } \\
\text { Tenggara } \\
\text { Timur }\end{array}$ & $\begin{array}{c}22.08 \pm \\
0.98\end{array}$ & $\begin{array}{c}41.45 \pm \\
1.79\end{array}$ & $\begin{array}{c}6.50 \pm \\
2.99\end{array}$ & $\begin{array}{c}1.74 \pm \\
0.76\end{array}$ & $\begin{array}{c}69.83 \\
\pm 0.82\end{array}$ & $\begin{array}{c}1.99 \pm \\
1.08\end{array}$ & $\begin{array}{c}567.53 \pm \\
32.33\end{array}$ & $\begin{array}{c}36.24 \pm \\
0.71\end{array}$ \\
\hline $\begin{array}{l}\text { Kosambi } \\
\text { tree from } \\
\text { Nusa } \\
\text { Tenggara } \\
\text { Timur }\end{array}$ & $\begin{array}{c}23.86 \pm \\
1.24\end{array}$ & $\begin{array}{c}43.70 \pm \\
2.04\end{array}$ & $\begin{array}{c}7.90 \pm \\
2.32\end{array}$ & $\begin{array}{c}3.03 \pm \\
0.82\end{array}$ & $\begin{array}{c}50.21 \\
\pm 0.79\end{array}$ & $\begin{array}{c}2.21 \pm \\
1.83\end{array}$ & $\begin{array}{c}951.29 \pm \\
31.24\end{array}$ & $\begin{array}{l}129.84 \\
\pm 1.58\end{array}$ \\
\hline $\begin{array}{l}\text { Kosambi } \\
\text { tree from } \\
\text { Ambon }\end{array}$ & $\begin{array}{c}24.57 \pm \\
0.54\end{array}$ & $\begin{array}{c}48.00 \pm \\
2.37\end{array}$ & $\begin{array}{c}9.21 \pm \\
3.43\end{array}$ & $\begin{array}{c}3.02 \pm \\
0.80\end{array}$ & $\begin{array}{l}49.46 \\
\pm 1.35\end{array}$ & $\begin{array}{c}2.30 \pm \\
1.04\end{array}$ & $\begin{array}{c}908.97 \pm \\
38.83\end{array}$ & $\begin{array}{l}125.45 \\
\pm 1.34\end{array}$ \\
\hline $\begin{array}{l}\text { Jambu Bol } \\
\text { from } \\
\text { Ambon }\end{array}$ & $\begin{array}{c}23.98 \pm \\
1.02\end{array}$ & $\begin{array}{c}49.60 \pm \\
1.56\end{array}$ & $\begin{array}{c}10.34 \\
\pm 2.48\end{array}$ & $\begin{array}{c}4.90 \pm \\
0.95\end{array}$ & $\begin{array}{c}57.50 \\
\pm 1.64\end{array}$ & $\begin{array}{c}1.11 \pm \\
0.62\end{array}$ & $\begin{array}{c}635.14 \pm \\
40.02\end{array}$ & $\begin{array}{c}73.38 \pm \\
0.97\end{array}$ \\
\hline
\end{tabular}

HMF: Hydroxymethylfurfural

\subsection{Acidity}

Acidity. The initial ranges of free acidity for studied honey samples were $18.01 \pm 1.43 \mathrm{~mL}$ $\mathrm{NaOH} / \mathrm{kg}$ (rubber honey in Jawa Barat) to $49.60 \pm 1.56 \mathrm{~mL} \mathrm{NaOH} / \mathrm{kg}$ (jambu bol honey in Ambon). According to The National Standardization Agency of Indonesia [10], these values are acceptable (below $50 \mathrm{~mL} \mathrm{NaOH} / \mathrm{kg}$ ). The free acidity of honey can be defined with the aid of taking into account the presence of organic acids in equilibrium with their 
corresponding lactones, or internal esters, and a few inorganic ions, inclusive of sulfate, chloride, and phosphate [14]. Thermal treatment did not significantly affect the free acidity compared to Table 1 to Table 2 and 3.

\subsection{HMF}

HMF is identified as a marker of honey freshness and significant deterioration because of the motion of usual honey acidity on decreasing sugars. The HMF content material tends to grow at some point in the processing or growing old of the product. Several factors influence the levels of HMF. Considered one of them is temperature and time of heating. Thus, it indicates overheating and storage in poor situations [14].

In this study, the mean values of initial HMF content were ranged from $5-30 \mathrm{mg} / \mathrm{kg}$ [13], indicating the freshness of the honey and good storage condition. Jambu bol honey in Ambon showed the highest initial level of HMF $(10.34 \pm 2.48 \mathrm{mg} / \mathrm{kg})$, and rambutan tree honey in Jawa Barat showed the lowest $(5.00 \pm 2.86 \mathrm{mg} / \mathrm{kg})$. HMF content in this study is increased gradually with different thermal methods by $75.60 \%, 94.82 \%$, and $107.02 \%$ using pasteurization, evaporator, and dehumidifier, respectively. Nevertheless, the suggested values for HMF content in three types of thermal methods had been still below the perfect acceptable limit based on national and international legal limits $(\leq 40 \mathrm{mg} / \mathrm{kg})$. This increase following the report of Zarei et al.[12], HMF content increased ranged from $81.3 \%$ to $108.3 \%$ using temperature-controlled water bath at $63^{\circ} \mathrm{C}$. Eshete et al. [13] stated that commercial pasteurization at $70-78^{\circ} \mathrm{C}$ and rapidly cooling at $32-40^{\circ} \mathrm{C}$ minimize heat damage. After pasteurization, diastase activity and HMF content remain almost unchanged because this temperature is similar to beehives and does not affect the honey.

\subsection{Diastase Activity}

A notable disparity turned into determined in the preliminary diastase activity among the fresh samples. For instance, rambutan tree honey in Jawa Barat had the highest diastase activity $(22.90 \pm 0.80 \mathrm{DN})$, while eucalyptus honey in Nusa Tenggara Timur showed the lowest value $(1.74 \pm 0.76 \mathrm{DN})$. These discrepancies are due to the honey from wild forest honey bees.

Blidi et al. [15] noted that these discrepancies are due to the honey's floral origin and the species of bees. However, all the honey samples complied with the SNI limits for diastase activity (min $1 \mathrm{DN}$ for wild forest honey bee and $\min 3 \mathrm{DN}$ for honey bee cultivation). The diastase activity decreased within the different thermal treatments attaining a maximum decrease after heating using a dehumidifier under the limit of about $58.26 \%$. On the other hand, pasteurization and evaporator decreased the diastase activity by about $6.70 \%$ and $25.93 \%$, respectively. Eshete et al. [13] pronounced the same thermal treatment that long heating periods of 60 to $90 \mathrm{~s}$ at thermal degrees of 30,50 , and $70{ }^{\circ} \mathrm{C}$ reduced the diastase activity of honey via almost $50 \%$ of its unique value. The heating of honey above $90{ }^{\circ} \mathrm{C}$ affects the caramelization of sugar.

\subsection{Reducing sugar and non-reducing sugar (sucrose)}

In general, sugars and different components of honey may also alternate during storage. While honey is heated, sugars decompose to form unwanted compounds (which include furfural and furan). They are related to non-enzymatic browning reactions (i.e., Maillard reaction, sugar degradation in an acidic medium caramelization) [16]. The sugar 
composition depends highly on bees' type of flower and regional and climatic conditions. Reducing sugar presents values of initial honey varying from $49.46 \pm 1.35 \%$ (kosambi tree honey in Ambon) to $73.09 \pm 0.81 \%$ (rubber tree honey in Jawa Barat). This result is similar to Mouhoubi-Tafinine et al. [17] research, reducing sugar produce values varying from $62.75 \%$ to $76 \%$.

The Sucrose level ranged from $0.40 \pm 0.26$ (Honewdew in Jawa Barat) to $2.30 \pm 1.04 \%$ (Kosambi tree in Ambon). Sucrose content material for all samples fell inside the limits of the Codex Alimentarius (5\%). The excessive sucrose content may also suggest a spread of adulterations, including cane sugar or subtle beet sugar. Moreover, early harvest indicated that the sucrose turned completely transformed into fructose and glucose; or extended artificial feeding of honeybees with sucrose syrups[18]. The presence of low sucrose levels suggests the opportunity that honey has been unadulterated with invert syrup.

\subsection{Total phenolic and flavonoid}

Folin-Ciocalteu's method evaluates overall total phenolics in many samples, along with honey. Phenolic compounds encompass distinct subclasses (usually flavonoids and phenolic), displaying many systems, some of which may interfere in the assay. Honey samples typically contain a number of these compounds, increasing absorbance values and overestimating the phenolic compounds [12].

The present study confirmed that the total phenolic content (mg tannic acid/kg honey) numerous many honey kinds. The lowest preliminary value was determined in rubber tree honey in Jawa Barat, where the average result of the samples was $372.40 \pm 46.31 \mathrm{mg} / \mathrm{kg}$, and the highest initial value was kosambi tree honey in Nusa Tenggara Timur (951.29 \pm $31.24 \mathrm{mg} / \mathrm{kg}$ ). Those data are similar to research by [12], where the average result of the multiflora honey became $462 \pm 53 \mathrm{mg} / \mathrm{kg}$, growing further in thyme $(538 \pm 41 \mathrm{mg} / \mathrm{kg})$ and lotus $(609 \pm 60 \mathrm{mg} / \mathrm{kg})$ honey.

Total phenolic content decreased after all thermal methods in rubber tree honey, kosambi tree in Ambon samples, and pasteurized method in rambutan tree honey in Jawa Barat and kosambi tree honey in Nusa Tenggara Timur, while in others it increased. Total phenolic content decreased after pasteurization, evaporation, and dehumidification were $4.00 \%, 1.18 \%$, and $3.39 \%$, respectively, in rubber tree honey in Jawa Barat. At the same time, kosambi tree honey in Ambon was $25.98 \%, 14.60 \%$, and $14.47 \%$, respectively. In rambutan tree honey in Jawa Barat and kosambi tree honey in Nusa Tenggara Timur, after the pasteurization process, total phenolic content decreased by $5.33 \%$ and $11.81 \%$, respectively. 
Table 2. The physicochemical quality properties of the thermal honey sample

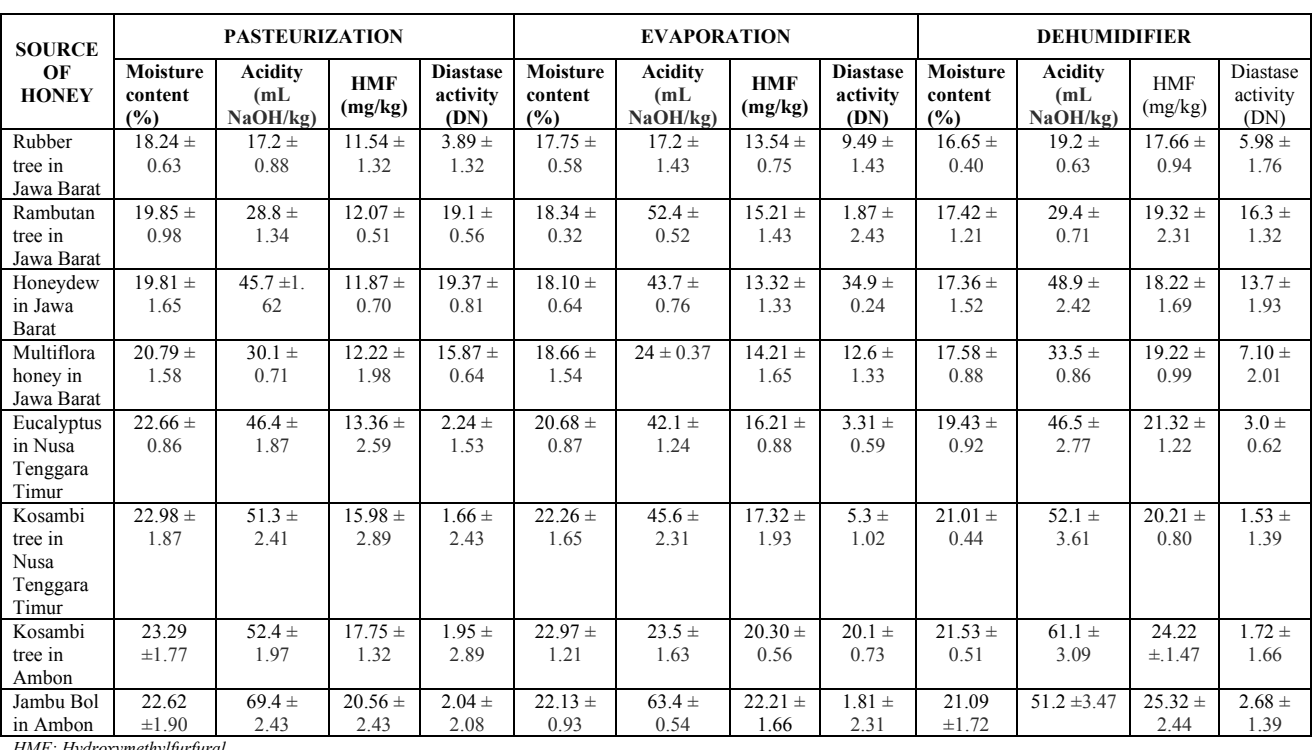

HMF: Hydroxymethylfurfur 


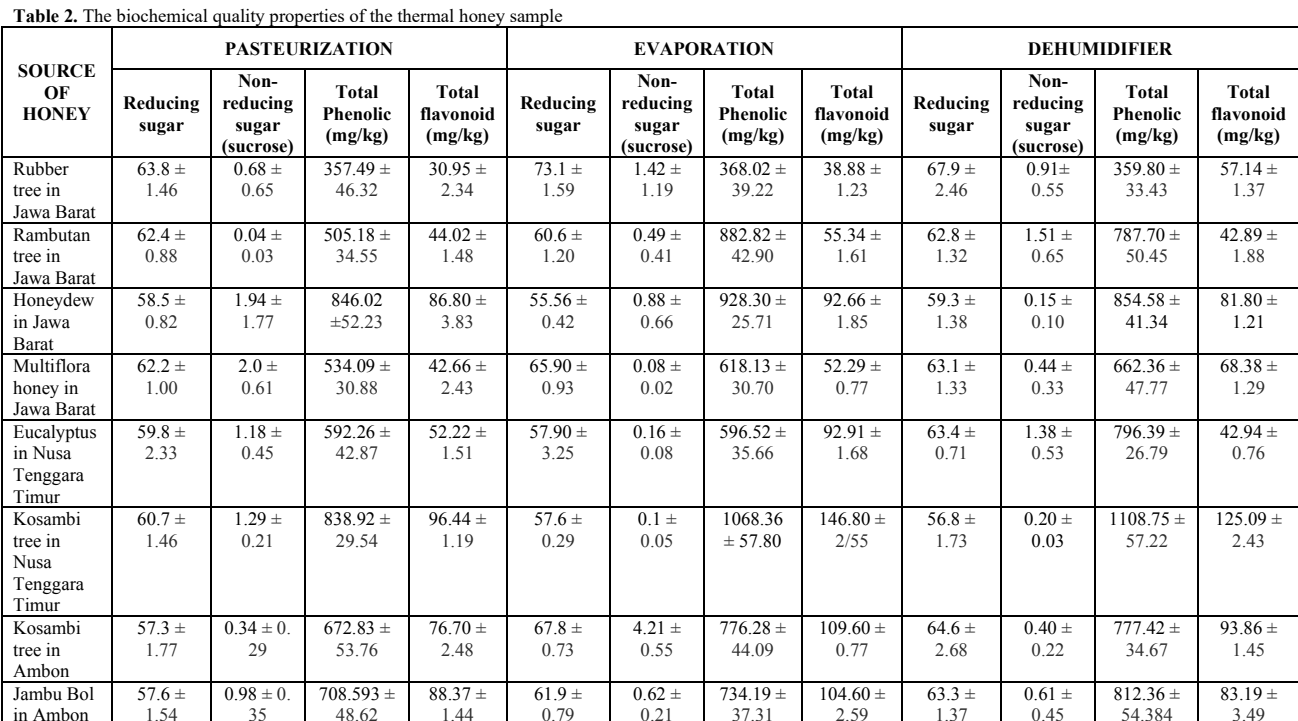

HMF: Hydroxymethylfurfural 
In contrast, the other honey showed the thermal treatment increased the total phenolic content as liberated phenolic compounds and thus increased the number of active compounds in the honey. According to Šarić et al. [19], heating honey at $95^{\circ} \mathrm{C}$ for $5 \mathrm{~min}$ no longer affects its antioxidant activity and total phenolic content. Aydogan-Coskun et al. [20] commented that the simple phenolics could increase due to the breakdown of supramolecular structures containing phenolic groups.

\section{Conclusion}

The study has shown that the heating of honey reduces the moisture with a subsequent rise in HMF and acidity. The thermal treatment decreased moisture content by $5.88 \%$ using pasteurization and $8.41 \%$ using evaporation. The most affected was by the dehumidifier decreased around $14.09 \%$. During the thermal treatment, physicochemical and biochemical analysis of different types of honey have been altered. Among the physicochemical characteristics, dehumidifier increased HMF content and decreased enzyme diastase were more prominent. In line with the biochemical properties of honey, total phenolic decreased significantly during the pasteurization treatment. Although the percentage decreased moisture content is lower than dehumidifiers, it is recommended to conduct thermal treatment by evaporation. It could maintain HMF and the diastase activity within the standard for honey quality.

This study was supported and funded by RISPRO LPDP (Indonesia Endowment Fund For Education), the Ministry of Finance of the Republic of Indonesia (PRJ-45/LPDP/2019)

\section{References}

1. I. Singh, S. Singh, J. Food Sci. Technol., 55, 3861-3871 (2018)

2. B. Fallico, M. Zappala, E. Arena, A. Verzera, Food Chem., 85, 305-313 (2004)

3. R. Subramanian, H. U. Hebbar, N. K. Rastogi, Int. J. Food Prop., 10, 127-143 (2007)

4. R. S. Gill, V. S. Hans, S. Singh, P. Pal Singh, S. S. Dhaliwal, J. Food Sci. Technol., 52, 6695-6702 (2015)

5. S. Singh, R. S. Gill, P. P. Singh, Int. J. Ambient Energy, 32, 62-69 (2011)

6. Z. W. Cui, L. J. Sun, W. Chen, D. W. Sun, J. Food Eng., 84, 582-590 (2008)

7. S. Kowalski, M. Lukasiewicz, S. Bednarz, M. Panus, Czech J. Food Sci., 30, 21-26 (2012)

8. S. A. Wibowo, A. Lastriyanto, E. Erwan, F. Jaya, J. Batoro. Quantum Teknika, 2, 66$74(2021)$

9. A. Lastriyanto, S. A. Wibowo, E. Erwan, F. Jaya, J. Batoro, D. Masyithoh, J. S. A. Lamerkabel, JMEST, 4, 153-163 (2020)

10. The National Standardization Agency of Indonesia, Honey (Madu), SNI 8664 (2018)

11. J. A. Pontis, L. A. M. A. da Cota, S. J. R. da Silva, A. Flach, Food Sci. Technol. Campinas, 34, 69-73 (2014)

12. M. Zarei, A. Fazlara, N. Alijani, FFHD, 9, 593-605 (2019)

13. Y. Eshete, T. Eshete, Madridge J Food Technol., 4, 158-162 (2019)

14. H. M. Habib, F.T. Al Meqbali, H. Kamal, U. D. Souka, W.H. Ibrahim, Food Chem., 153, 35-43 (2014) 
15. S. Blidi, P. Gotsiou, S. Loupassaki, S. Grigorakis, A. C. Calokerinos, Adv. Food Sci. Eng., 1, 1-8 (2017)

16. C. Thamasopinkul, P. Ritthiruangdej, S. Kasemsumran, T. Suwonsichon, V. Haruthaithanasan, Y. Ozaki, JNIRS, 25, 36-44 (2017)

17. Z. Mouhoubi-Tafinine, S. Ouchemoukh, M. Bachir bey, H. Louaileche, A. Tamendjari, IFRJ, 25, 1044-1050 (2018)

18. P. M. Da Silva, C. Gauche, L. V. Gonzaga, A. C. O. Costa, R. Fett, Food Chem., 196, 309-323 (2016)

19. G. Šarić, K. Marković, D. Vukičević, E. Lež, M. Hruškar, N. Vahčić, Czech J. Food Sci., 31, 601-606 (2013)

20. B. Aydogan-Coskun, H. Coklar, M. Akbulut, Food Sci. Technol., 40, 629-634 (2020) 